\title{
Challenges of Western Balkan Countries on Their Road to EU Integration
}

\author{
Mirvan Xhemaili
}

\begin{abstract}
Western Balkans is one of the regions that has experienced the worst and the longest transition after the Cold War. The dissolution of Yugoslavia at the beginning of 1990s was associated by destructive interethnic conflicts, by local and regional wars, and also by political and ethnic accidents. Western Balkans is also closely related to Europe politically and economically. The historical period to be considered in this research is the post-Cold War period, after the immense changes in central Europe, and the southeast Europe, i.e. the Balkans. The international factor has actively intervened in the Balkans. The international presence is both military and civil. Various international mechanisms have played a determining factor through direct activities in the region. The process of dissolution of former Yugoslavia has fragmentized the Western Balkans in many spheres, starting from the border changes to demographic changes. This process also resulted in creation of new states that changed the geopolitics of the region. The fragmentation was caused by many factors: historical, political, economic, military, geopolitical, and strategic. Also, this development was determined by the political concepts that are leading the region in respect to EU integration. The development of the regional political process has now conditioned and oriented the Western Balkans towards integration in Euro Atlantic structures. Knowing that these countries have as a strategic aim the full membership in the EU, I can say that this makes the process more dynamic and faster, because we are dealing with a process that entails the same principles and same values that are closely related to regional interests. Regardless of the same orientation on values and geopolitical interest, the Western Balkans is currently in a fragmentized level in regards to EU integration.
\end{abstract}

Keywords: Europe, Balkan Region, conflicts, cooperation, integration.

\section{Introduction}

The European Union map remains open for the Western Balkans ${ }^{1}$ and the Balkan countries should be on the edge border of EU. The European map would be considered incomplete without the countries of the Western Balkans. Unlike the other part of Eastern Europe, the Western Balkans is one of the regions that has experienced the most difficult transition after the Cold War. At the aftermath of post-communist transitions when most Central and Eastern European countries embarked on a process of deep economic and political change, the Balkan countries remained entrenched in a series of ethnic conflicts, succession wars and endemic circles of instability. The Western Balkans of the last 25 years had former Yugoslavia as a central issue. The dissolution of Yugoslavia resulted to seven independent states. After the wars that followed the initial proclamation of independence in several of these countries, a period of consolidation ensued, along with European integration as well as reconciliation efforts. During this period, the EU was engaged in the region through leading a series of peace-keeping missions and paying the lion's share of assistance. By 2000s the EU has promised to turn a leaf and lead those countries into stable, self-sufficient democracies, at peace with themselves and each other, with market economies and the rule of law. This article seeks to identify and analyze the problems and challenges of transition, the political, economic and social transformations, the process of policy-making in these countries of the Western Balkans, the external and internal factors, the nature and the role of national actors and the political leadership in this process. The article also seeks to uncover the impact of the EU in the Western Balkans political transformations. Approaching the EU impact on Western Balkans political reforms as a process of countries' socializations to the norms institutionalized in the European environment, this study dwells on both the external and domestic factors that determine the mechanisms of norm

\footnotetext{
1 The term the Western Balkans means, the States that that emerged of the collapse of the ex-Yugoslavia, including Albania. So countries such as Kosovo, Albania, Montenegro, Bosnia-Herzegovina, Macedonia, Serbia and Croatia. In this study would not have treated the case of Croatia, because it is already a member with full rights in the European Union from 1 July 2013.
} 
assertion in the domestic areas. European Union to the Western Balkans, and the opportunities and challenges that this will bring about. We will focus on the political dimension of this process, particularly in meeting the Copenhagen criteria. Particularly, the principal objective of this paper is to explain the reasons that led to the wars in Western Balkans and the EU initiatives that were supposed to help in resolving these problematic issues and to facilitate the accession of the countries of the region to the European Union. Regardless of the effort jointly performed by the EU as well as countries from the region, this research shows that a lot of work will still have to be done before all of the countries become adequately developed in a political, economic and societal sense to become members of the European Union. The origins of the European idea and the formation of the European community after the Second World War lie in the aspiration to prevent further wars among European nations. As stated in the Schuman Declaration of 1950: "One of the main goals of the original idea of European integration is defined as preserving peace in the Member States". In this research, we argue that the same concept should be applied to the territory of Western Balkans, that is, that the European integration of the region could help to preserve peace in the region while also providing stability and, consequently, political and economic growth. Furthermore, as D. Trenchov (2012:5) argues, we note the growing need for interdependence amongst all of the European nations and states on different political and societal levels. Moreover, as the central aim of the process of European integration is twofold - entailing of stabilization as well as accession-we critically assess the relative value of the European Union applying either a regional or individual approach to the respective countries in the process of accession. Regardless of similar orientations in geopolitical interests, the Western Balkans is at the stage of fragmentation because of its past legacy and transition difficulties concerning integration in the EU. Political and economic developments in the region have been unsatisfactory. Reasons for this include security issues and the slow transition. In the beginning of the 1990s, and especially after 1992, the relations between the countries of the Western Balkans and the EU were organized based on the Trade and Cooperation Agreement. The key purpose of this agreement was to inspire economic and market reforms in order to prepare for an association agreement with the EU. As regards to the regional approach the European Union in 1996 made a differentiation between the two terms 'South-East (SE) Europe' and 'Western Balkans'. 'SE Europe' refers to all of the countries from the Gulf of Trieste to the Black Sea, while Western Balkans consists of "Yugoslavia minus Slovenia plus Albania" (Alibali 2003). It could be said that generally the relations between the EU and the Western Balkans countries are evolving and that the EU has embraced a good methodology to the region since it has brought progress as well as cooperation between the conflicted countries. This is particularly apparent in the bilateral and multilateral meetings organized by or with the support of the European Union where political leadership of these countries gather and take common decisions that are valuable for the whole region. However, we notice that more should be done on the level of civil society, where efforts would have a direct impact on citizens. Another problem might be the often noticed difference in discourse chosen by politicians depending on whether they are addressing domestic or international audiences. The key argument of this study is that the selected EU method of imposing political dialogue in the region is correct and should be further developed. Saying this, we underline that the countries that emerged from the former Yugoslavia (Including Albania) are relatively small countries that need mutual support in many different policy areas as well as in the process of EU accession. Besides the value derived from cooperation at the official level, the citizens of these countries will benefit more by working together, cooperating in the fields of culture, education and business. We must say that all earlier enlargements of EU had encouraging impact by providing the new momentum for reform of all aspiring countries involved. The enlargement of market, economic growth, financial and monetary strengthen and stability are just some of the prerequisites that increase the EU in as a global actor to escape from traditional shell. The process of EU enlargement involves conditioning, assisting, monitoring and checking a candidate country's capacity to be an EU member.

\section{European Integration of Western Balkans: From reconciliation to the European future}

After the World War II, Yugoslavia became a leading country of Non-Aligned Movement during post war period, and the greater part of the rest of the world divided itself into two ideologies -Western and Eastern that was more than a reason for the initiation of the Cold War. (Maleski, 2012). The dissolution of Yugoslavia generated the open angers between the new independent countries. Open conflicts and disputes between the newly formed independent countries and the part of Yugoslavia that wanted to preserve the status and conditions from before, created a lot of problems and difficulties for Europe and incited its inspiration commitment in the Balkans. Setting up a two-side problem, efforts were made to find an acceptable The Enlargement policy has been considered as the most successful and powerful policy. The Enlargement policy has helped many European states to transform into functioning democracies, and also into prosperous countries. The EU has long viewed the enlargement process as an extraordinary opportunity to promote political stability and economic prosperity in Europe. The logic of functionality seeks to address the weak state structures and institutions that 
resulted from the post-communist transition, the ethnic wars, the intrusive and heavy-handed external interference and the lack of capacity and experience of the new independent states, successors of former Yugoslavia. State weakness has become the main challenge of the region and refers to the lack of the rule of law, flourishing organized crime and corruption, and illegitimate and no representative institutions (UNDP 2002). Western Balkans countries are all geopolitically oriented towards EU, but the transition process in these counties is ongoing. The European Union has been committed to help these countries to consolidate their states and develop their stable institutions as well as their economies. The EU has made many times clear that its policies are in favor of including these countries to the club of the 28 member states. The prospect of joining the $\mathrm{EU}$ is the greatest guarantee and the most powerful stimulus for democratization and progress of Western Balkan countries and that the EU, because of the political conditionality attached to the financial aid, will have a considerable and positive impact on domestic reforms and transformations. The process of integration in the European Union is both political and technical. It is political considering the fact that all the aspiring Balkan countries are oriented geopolitically towards the European Union, and all of these countries have EU integration as a national strategic objective. Also, even within EU there should be a unanimous consensus to be in favor of the enlargement process. It is technical process because in order to join EU, these countries have to fulfill certain criterion (Copenhagen Criterion) and standards. The process of EU integration has helped these countries consolidate their states and their democracies. By 2000s the situation in the Western Balkans was resolutely different from the vicious circle of nationalism, violence and authoritarianism that had locked-in their distinct path of transformation in the first decade of transition. The Balkan countries from the outset have distinguished themselves for their specific and challenging path of transition. The historical transformation that started with the fall communism in 1989 had all the premises to be particularly challenging. Not only did it involve a triple and simultaneous transformation of both the economy, politics and in some occasions states themselves, but it also involved dealing with the particular legacy of communism as a distinct form of organization (Eckiert and Hanson 2003). The process of integration of Western Balkans in the EU is characterized by many challenges and distinguishing characteristics: the post-communist challenge, the post-conflict challenge, and the challenge of decriminalization of political arena.

\section{Post-Communist challenge:}

The countries of the Western Balkans have made great strides in overcoming the legacy of a half century of communism and introducing wide-ranging reforms. All of the Balkan Countries aspiring to join the EU have been communist countries. The transformation of political leadership in Western Balkans during the presents an interesting phenomenon. Both former Communist leaders as well as new democratic leaders became nationalists in the newly formed states. The wars were used by former Communist leaders in order to stay in power. They also delayed the political democratization of the former Yugoslav states, State building within the states of the former Yugoslavia coincided with the post-conflict transition as well as the transition to post-Communist rule, which made the situation difficult. We can easily see elements of authoritarian decision making process by the political leadership in the Western Balkans, and the political leadership is responsible for the insufficient reforms and the slow rhythm of changes that have been done in the countries until now.

\section{Post conflict challenge}

The countries of Western Balkan region (1991-1998) also had a recent history of violent instability, wars and ethnic conflicts and divisions, representing in this way a bigger challenge for both themselves and the EU. (Balfour, 2011). The main reason for these wars and conflicts were the unsolved national disputes among these countries. During this period, the EU was more concerned in reconciliation of the region, repairing the damage, the security issue, respectively the financial support. The foundations of democracy, the rule of law, political dialogue and human rights are still being established in these countries. At the same time, these are all criteria posed by the European Union for countries seeking to become members, which is the goal of all Western Balkans countries. Currently, they are all declaratively typical democracies showing higher or lower levels of functional democratization. However, there are many bilateral disputes between neighboring countries within the region. The relations between these states are still burdened by the previous wars. The strategic issues that these countries need to deal with in order to advance bilateral relations, but also in order to gain access to the European Union, are border issues between the respective countries. The process of transformation from a centrally planned to a market economy is a huge and multidimensional task, which requires incorporation of the principles of market liberalism, free and open markets, liberalization, privatization, deregulation, labor market flexibility and minimal state intervention. The countries of the Western Balkans have made important progress in economic stabilization and in their 
macro - economic system. The main of the SAP, the SAA, focuses on respecting for the key democratic principles and the development of a market economy with the integration of the country into the EU single market

\section{The challenge of decriminalization of political arena}

If one analyzes the progress reports that the EU Commission issues yearly for countries of the Western Balkans, it is obvious that continually there are some fields that have been criticized constantly, such as: corruption, organized crimes, free elections, media and so on. In this regard, it is worth mentioning that the wide ranging organized crime and its links with the structures of power and political elites are a bad sign of any governance of law and seriously impede the progress of the countries. This sign and its infiltration in various domains of public and political life are linked to the absence of statehood and poor or even severe economic situation. Therefore, it is important to mention the recent law that has been passed by the Assembly of Albania on decriminalization of political arena, and other countries should take this as an example to keep the criminals out of public and political life.

\section{EU approach to the Western Balkans}

The enlargement policy has long been considered as the EU's most successful tool for democratizing transition countries. The experience of Central and Eastern European countries during the 2000s undoubtedly supported this belief, while comforting the EU's legitimacy in its role of transformative power. Nevertheless, the Western Balkan democracies have not made any improvement recently. Populism and authoritarian temptations have put Western Balkans' civil society under greater pressure; they have weakened key institutions guaranteeing the rule of law and harmed political pluralism and electoral processes. Young people, in particular, seem estranged both from the political systems as well as increasingly from the idea of European integration making a contribution to their lives. The abridgement of freedom of the media, the degradation of parliamentary democracy, the rise of political radicalization, clientelism and voter abstention have become markers in many Western Balkan democracies The European Union decided on using a regional approach in this part of Europe in order to achieve greater stability among the conflicted states and a normalization of relations between them. Its role is predominantly stabilizing, as each country has applied for, or expressed interest in, acceptance into the EU. The European Union was committed to facilitate the process of transformations and reconstruction in the region of the Western Balkans, therefore, the agreement formula for the Western Balkans was a new strategy with a regional dimension, called the "Stabilization and Association Process (SAP) (Elbasani, 2013). This is a framework in which a contractual relationship - the Stabilization and Association Agreement (SAA) and an assistance program (CARDS) - help each country to progress towards EU membership.(Bello, 2010) The SAP is a long term policy for moving gradually from stabilization and reconstruction to association and sustainable development in a flexible and dynamic process. By introducing European values, principles and standards to the transition countries it aims to help with their reforms, bringing them closer to EU membership (European Commission 2003:2). The SAP has been complemented by another project which is also an EU initiative, the Stability Pact for South - Eastern Europe. The Stability Pact focused on democratization and human rights, economic reconstruction and development and security issues, with the aim of accelerating the transition of the countries towards stable democracies, market economies and open pluralist societies. It would help faster integration of the region into the EU structures. To benefit, countries had to co-operate and work on tensions and crises in the region, develop good regional relationships, create free trade areas, and fight against organized crime, corruption and all forms of criminal activities. (World Bank 2000) The EU has continued to show its readiness to support the countries of the Western Balkans continuously, so in 2003 the SAP was confirmed by the Thessalonica Summit as the overall policy framework. Later, in 2004 the European Commission approved the first ever "European Partnerships for the Western Balkans. The preparation of the Balkan countries for integration into European structures is a major priority of the EU. The Summit of Thessalonica in June 2003 was a milestone in the relations of the EU with the Western Balkans. The Summit sent a strong political message to the countries and the people of the Western Balkans: their future lies in integration into EU structures, EU is committed to the European future of all Balkan countries, and the Europe will be fully re-unified only after this region has become an integral part of it. The rate of progress of this integration, however will depend on the performance of the countries themselves and on a wide range of reforms. Countries that wish to join the EU and become its members, have to follow a certain path, which for some countries is long, difficult and requires a lot of hard work. This path is a set of technical stages as below: 
Pre - Accession Process: trade, cooperation and association agreements

Accession - Process: candidate status

\section{EU Membership: membership status}

The objectives of the Pre-Accession Process are created not only for integrate the Western Balkans in the EU, but also to eventually overcome ethnic conflicts in the region. For the effective implementation of the standards required from EU, which are the criteria defined in the European Partnership documents the EU rewards each applicant country with additional funds for Pre-Accession Assistance (IPA) for the implementation of the reforms. Also, the process of integration is based on certain criterion established by the EU. In 1993, the Council of Europe of Copenhagen set out political, economic, legal, and administrative criteria for membership in the EU. (European Council 1993: 1). The political criteria requires countries to have stable institutions that ensure democracy, the rule of law, human rights, and respect and protection of minorities. The economic criteria requires countries to have a functional market economy, as well the capacity to face the pressure of competition and strength of the internal European market. The legal criteria require candidate countries to make their national legislation compatible with that of the EU and to have the ability to implement the EU body of laws and regulations. The administrative criteria requires that the candidate countries have the administrative capacity to implement the laws and policies and of the EU. Regional cooperation: European integration and regional cooperation are closely intertwined. One of the key aims of the SAP is to encourage countries of the region to cooperate among themselves across a wide range of areas, including the prosecution of war crimes, border issues, refugees and the fight against organized crime. One of the specific components of the IPA is dedicated to regional cooperation and cross-border programs. Visa-free travel: Visa-free travel to the Schengen area was granted to citizens of the Former Yugoslav Republic of Macedonia, Montenegro and Serbia as of December 2009, and to citizens of Albania and Bosnia as of November 2010. In January 2012, a visa liberalization dialogue was launched with Kosovo. In its May 2016 fourth report on Kosovo's progress in this area the Commission concluded that Kosovo had met all the requirements, but that two outstanding issues should be dealt with by the day of adoption of its proposal by the European Parliament and the Council. Countries of the Western Balkans - Albania, Bosnia, Croatia, Macedonia, Serbia, Montenegro and Kosova have understood that reforms in establishing democratic and stable institutions, creating a functional state based on the rule of law, creating a market economy, and increasing the role of citizens in society; are the best path to a new future in peace, stability, prosperity, and freedom. Hence, the EU has helped the countries of the region during the course of transition, particularly the countries of the Western Balkans. This support and assistance aims at planning their accession into the EU as member states as soon as they meet the needed standards. The EU has always shown a willingness to promote the membership of the Western Balkans, but the EU's approach will be promoted only as long as the region and the countries individually continue to reform their political and economic systems. The EU always reminds the countries of the Western Balkans that the assessment on their membership will be taken on the basis of individual progress, disregarding all uncertainties that there is alternative way for the region to integrate in the EU. Although the consensus among member states of the EU exists about the constructive impact on EU enlargement policy, on political stabilization and socio-political development in the Western Balkans, it is expected that the accession of Western Balkan countries will be a challenge to the existing and the new member states. This describes the differences in the approaches of European political elites and citizens concerning their support for the membership of the region to the EU. It is clear that the implementation of the EU standards by the Western Balkan countries will have a crucial effect on the willingness for enlargement. The effects 'of enlargement fatigue' that would be caused the by the membership of the Western Balkan countries and the concerns of delaying the process of internal reform within the EU institutions must be taken into account. This "enlargement fatigue" displays a problem that the EU member states face. Specifically, they have to choose between internal growth and development, which is a priority to the EU, and the enlargement. It is thought that the most beneficial result in this regard is the mixture of these two goals, profiting from the EU enlargement, in parallel with keeping its unity and internal efficiency. The enlargement strategy is centered on the principle of conditionality - the offer of the EU rewards (most importantly financial assistance and membership) on the condition that WB states meet the demands set by the EU. In order to support the development of Western Balkan countries in 2006 the EU adopted the Pre-Accession Instrument (IPA) 2007-2013 as a form of financial assistance. It is expected that many of the institutional and development priorities identified in Western Balkan countries will receive financial support through the IPA over the next few years. The perspective of integration of the Western Balkan countries in the EU has played a central role in political, economic and social stabilization by relaxing the effects of internal conflicts and efficient 
transformations. Even if the progress of the Western Balkan countries towards EU integration continues with varying dynamics, the hope of possible membership is an important factor and catalyst to continue with the reforms. It will take hard work and the political will of those in power in the region. So, with sufficient political will and ability to reform and endorse the core values and the principles of the European Union, the countries of the Western Balkans, among them Albania, will be next in line. The present situation is the following: the EU has developed a policy to support the gradual integration of the Western Balkan countries with the Union. On 1 July 2013, Croatia became the first of the seven countries to join, and Montenegro, Serbia, the Former Yugoslav Republic of Macedonia and Albania are official candidates. Accession negotiations and chapters have been opened with Montenegro and Serbia. Bosnia and Herzegovina and Kosovo are potential candidate countries. (European Parliament)

\section{Challenges and Perspectives: The internal and external political challenges of the Western Balkans Countries}

The EU integration process is a highly complex process which comprises of the design and implementation of reforms in a wide range of areas. The experiences of new EU member states as well as those currently in different phases of their EU integration process clearly indicate that working simultaneously in many areas and making decisions about complex political, economic, legal and institutional issues with long-lasting consequences for the everyday life of citizens is far from an easy task. The challenge of European integration can encourage the development and functioning of democratic institutions capable of dealing a rapid and complex transition involving areas such as cultural, economic, institutional and political life. The determination made on the way to EU integration will generate the conditions for a modern market economy and boost these countries' capabilities to compete within the EU. The countries of the Western Balkans have been slow to adopt the EU integration process. The most important challenges such as these countries' economic and political problems persist unsolved. This is because the countries of the region have not been able to resolve the regional challenges and achieve a political consensus. These challenges could deter the necessary political and economic reforms and the overall process of EU integration. The integration process depends on, particularly, the level of aspiring democracy, political stability and the position that have taken the governments and political elites to advance this process regardless of partisan interests and power struggles. The EU adopted in 1993 the Copenhagen Criteria for membership, creating a foundation for economic, political, legal and administrative development. The required standards by the EU would enable the region to improve significantly the standard of living for their nations and also bring it closer to the European family. Although the Copenhagen criteria had been established, the region was an arena of several wars in the 1990s. The wars between Serbia and Slovenia in 1991, Serbia and Croatia from 1991-1994, Serbia and Bosnia and Herzegovina from 1992-1995, Serbia and Kosova Albanians in 1998-1999, the civil unrest in 1997 in Albania, and the armed conflict in 2001 between ethnic Albanians and the government forces in Macedonia, not only hindered the process of fulfilling the Copenhagen criteria, but even worse, reversed any progress that had already been made towards integration (Reka and Sela, 2007). The development of regional political process has now conditioned and fully oriented the Balkans towards EU integration structures. Taking into account that all the countries of the Balkan region aim at full integration into the European Union, then we conclude that this makes the process faster and more dynamic because we are dealing with a process that involves the same principles and values which are closely related to regional interests. The main challenges of the Western Balkans countries on the road towards the EU deal with the commitment and dedication of the governments, which should address European integration as one of the most important priorities, establishing institutions, strategies, coherent and consistent plans, that ensure economic growth and walking quickly towards European Union (Reka, 2010). However some of the conditions set by the EU can have large effects on the political and economic system of the applicant country, this as the cause of the nature of EU intervention. The Western Balkans Countries found themselves having to build a system of democratic governance from scratch. These countries had to undergo a dual transformation, both political transformation and economic transformations. Countries of the Western Balkans: Macedonia, Albania, Kosova, Bosnia and Herzegovina, Serbia, and Montenegro continue to have difficulties: from high level of unemployment, organized crime, corruption, austerity measures, and lack of foreign investments. These problems directly hinder the process of integration in EU. The Western Balkans will remain a priority interest for the EU. If we examine the present-day political situation in the Western Balkans and in each country of the region individually, one can easily conclude that after all these efforts and commitments in the field by the EU, the problems and challenges are still evident in these countries. The region must overcome these problems through sincere cooperation with the international community to be part of it. The aspiration for EU membership remains an essential stabilizing factor in the region that also reassures fundamental reforms in each country. Two decades and a half after the fall of communism, the countries of Western Balkans have moved away from the exclusionary and violent ethnic politics that have characterized regime change in the first half of the 1990s, while reaching a critical mass in 
support of integration. Despite the fair share of differences among different countries in the region, Balkans in general seems to score low on all or most legacy-oriented factors that can facilitate post-communist transformation (Pridham and Gallagher 2000). Regardless of the fact that all countries of the Western Balkans have achieved progress in their path to EU membership, the dynamics of this process is the reason why some of these countries are closer to EU membership while others are lagging behind. The membership of the Western Balkan countries to the EU will depend on overcoming main difficulties linked with the persistent threat of internal political instability. This is affected by internal ethnic, religious or political struggles, some of which have worsened to such a point that it has paralyzed the implementation of government reforms. Furthermore, the countries of the region have weak internal structures, organized crime, and corruption which have created restricted effectiveness on the part of public administration and other state institutions. The successful processes of reconciliation in the region is needed to ensure the political stability is very important in this route to EU. The economic transformation and implementation of free trade values will also play a substantial role and guarantee economic growth. Political Challenges: One of the most challenging issues in the process of EU integration is the political challenge, there are in many cases situations when different political parties in the countries of the region that cannot reach consensus on matters that are considered crucial for the process of integration. Therefore, the unresolved political issues in the Western Balkans could pose a serious obstacle to regional co-operation, a good neighborhood, investment promotion and the European integration process. The low level of economic development indicates that the Western Balkans is lagging behind in meeting the European criteria for a sustainable and competitive economy. In addition to this, it is very important that the political leadership of these countries leave aside their political parties own interest aside when there are serious matters and reforms needed for the purpose of integration, There is also the problem of institutional effectiveness and the efficiency of administration in the various countries that have not yet achieved an adequate professional level. Open conflict remains a remote option across the whole spectrum of the countries merging from former Yugoslavia. Elites' appeal to nationalism and their chances to seize power through forging ethnic violence seem to be less attractive in the current constellation of political forces and public opinion. Liberal political parties, figuring reformists, have gained strength in government and society. From Croatia to Serbia and Macedonia, and even in the states that have experienced violent wars like Kosova and Bosnia, moderate politicians committed to reform and EU integration proved strong enough to compete with and sometimes replace nationalists. Political leadership of these countries should not use the integration importance only as a rhetoric, instead they should use the citizens will to join the EU as a motivation to undertake the necessary reforms needed for this crucial process. Institutional Challenges: The Western Balkan countries should accept the process of EU integration as an instrument which facilitates the transitional period and helps them accelerate reforms. This process should be used in a proper manner because, as the accession countries become exposed to regional and global competition within the context of EU membership, the negative impacts of a weak economic incentive and institutional regime will be felt more acutely (World Bank and European Commission, 2002). The first challenging field in the institutional picture of the Western Balkan countries is the lack of qualified professionals within the public administration to correspond effectively to the necessities for harmonization of the administration functions with European norms and models. Secondly, in the process of decentralization and transferring more power to local authorities, there are many hindrances and challenges that prevent this process from deepening and full implementation. Although it is enshrined constitutionally, the local government requires a series of additional measures to ensure its proper and independent functioning. It should be also highlighted that the Assembly (Parliament) is constitutionally structured as a supreme institution in most of the countries, but in practice, its powers are formal and limited. It is essential to strengthen the role of the Parliament in the internal and external processes, in the national and foreign affairs which means to strengthen the control over the executive power by the legislature. The founding of the institution of the ombudsman in each country is a positive tendency and can be perceived as a significant and required step towards a democratic legitimate state and a prerequisite for good governance. The stability of democratic institutions is one of the conditions of accession to the European Union. The countries of the Western Balkans have other challenges that have to be resolved before this region becomes part of the EU. Among many challenges, we will consider some of the most acute ones. We have to emphasize the fact that these post-communist cases, where the main impetus of reform has come mostly from external sources, thus lacking domestic ownership of the process. Knowing the fact that the process of integration takes a general involvement of all members of society, it is important to mention the involvement of the civil society in this process as well. Civil Society activities are another key feature of democracy and are essential for the promotion and respect for human rights and building the rule of law. Civil Society organizations can help the process of achieving increased political accountability as well as promoting public discussion of important political, economic and social issues which to improve the quality of reforms in these areas. Even though there is a reported advancement of the capacity and positions of the Civil Society for monitoring and evaluation of the government in each country, its impact is 
still weak and regular discussions with its representatives in the legislative process are lacking. In this regard, in its progress reports the European Commission makes recommendations for improving the social and economic dialogue between the Civil Society and the authorities at national, regional and local level. Free and fair elections, is additional main criterion for the improvement the democracy in each country. To ensure steadiness and respect for the rule of law, it is indispensable that elections are held in line with the relevant international and European standards. The elections held in the recent years in different countries of the region are generally carried out in accordance with the international principles as on the one hand there has been substantial improvement in the presence of various communities to vote, but on the other hand, there are still registered cases of using excessive violence and pressure on citizens during election time, which does not respond to the criteria for democracy. In addition to this, it is important to mention the case of Macedonia that has amended the electoral code recently, so that certain number of voters have to verify their right to vote within a certain amount of time given. The reform of the judicial system is on the one hand, one of the most subtle political criteria that should be met by potential candidates for EU membership, and in addition, it is a prerequisite for ensuring the rule of law as one of the defining values in the EU. Regarding the judicial reform in the countries of the Western Balkans it is significant to mention that its conduct needs both legislative and institutional changes. The European Commission most frequently calls for judicial efficiency and warns against non-transparent and unmotivated decisions for appointments of judges and prosecutors and their independence, as well as against the inadequate access to justice. The recommendations and criticisms of the EC shows that in the first place the Western Balkan countries need a comprehensive, integrated and coordinated strategy to reform their judicial systems. Another important pillar of democracy is the freedom of media and speech. The challenges facing all countries in the region include the intimidation of journalists, political pressure, corruption in the form of "custommade" articles and reports, illegal state subsidies to government-controlled media. There is lack of transparency regarding the ownership of major media groups and as a result there is blending of political, economic and corporate interests. So the space for serious discussion on important topics is reduced below the minimum health and leads to outright and intentional profanation of the fourth power. Western Balkans Countries have other challenges as well that need to be resolved before the countries join the EU. Other challenges include: The internal political dynamics: countries of the Western Balkans need to have responsible political leadership that is capable to take the necessary reforms and standards towards EU. In other words, there should be an internal political consensus for this major objective. The external political dynamics: Countries of the Western Balkans not only have to fulfill the Copenhagen criteria, but they have to strengthen their good neighborhood policy, which means that they have to build bilateral political and economic relations with their neighbor countries. (Bashkurti, 2006). There are many factors that gave rise to four types of present-day conflicts: bilateral border issues, ethno - religious conflicts, cultural and historical tensions and legal dispute. More should be done to overcome the current disputed issues. Knowing that the disputed Issues: wars and conflicts are a burden on the bilateral relations. A more proactive role from the EU should be done in this regard to resolve these disputes. Conclusion Having offered all potential difficulties and perspectives, one may doubt whether common European identity can really be achieved or whether countries of the Western Balkans will catch the European train. Despite the existence of numerous obstacles, the future looks optimistic. On one hand we have all the countries of Western Balkans having the integration in the EU as a priority strategic objective, and also a high percentage of citizens which are in favor of EU integration. On the other hand we have the EU constantly showing commitment to include these countries in the club of the 28 member states. The enlargement policy has long been considered as the EU's most successful tool for democratizing transition countries. The experience of Central and Eastern European countries in the 2000s certainly backed this belief, while comforting the EU's legitimacy in its role of transformative power. However, the state of Western Balkan democracies has not improved over the past decade. On the contrary, it has eroded in several cases. Populism and authoritarian temptations have put Western Balkans' civil society under greater pressure; they have weakened key institutions guaranteeing the rule of law and harmed political pluralism and electoral processes. Young people, in particular, seem estranged both from the political systems as well as increasingly from the idea of European integration making a contribution to their lives. The abridgement of freedom of the media, the degradation of parliamentary democracy, the rise of political radicalization, clientelism and voter abstention have become markers in many Western Balkan democracies. More should be done by the countries of the Western Balkans countries in fostering democracy and rule of law in the region, strengthening administration capacities, and improving internal and external security, but there are still serious challenges (related to corruption, organized crime, unsustainable economic models, open political issues and insufficient regional cooperation) that the region has to work on. In addition to this various aspects need to be considered seriously by the countries of the Western Balkans: The region has certainly turned a new leaf resolutely closing the tragic chapter of the 1990s and opting en masse for European integration, while the EU has uphold its active leverage extending the promise of membership under a new frame of enlargement. Yet, 
the issue facing the EU and the moderate elites across the Balkans is how to turn the bad story of the past into a successful story of new institution-building. This promises to be a long way ahead. On the one hand, the frame of enlargement tailored to the Balkans might be hampered by the lack of EU commitment and the vague promise of membership. On the other hand, the domestic scope conditions that characterize most Balkan states, despite of their differences and overall progress are still a challenge for both their fast transformation and process of Europeanization. Further research on EU effects in the region has still to trace the longer term impact of EU at the institutional level, which could display different degrees of compliance across different countries and areas of change. Ultimately, the degree to which EU tools translate into domestic change remains a puzzle for empirical research seeking to reconstruct the preferences of domestic actors and their state constraints in each particular case of reform. The countries of the Western Balkans have no other alternative other than join the European Union.

\section{Bibliography:}

[1] Alibali, A. "Ballkani Perendimorë apo Evropa Adriatike" Korrieri, Tirana, 2003, 36-30.

[2] Anastasakis, O, (2008) The EU's political conditionality in the Western Balkans: towards a more pragmatic approach Southeast European and Black Sea Studies Vol. 8, No. 4, 365-377

[3] Balfour. R and Stratulat. C (2011) European Politics and Institutions The Democratic Transformation of the Balkans PAPER NO.66

[4] Blerim Reka, Ylber Sela, "Hyrje në të drejtën e Unionit Evropian", Arbëria Design, 2007, 68-70

[5] Blerim Reka, "The Geopolitics and Techniques of EU Enlargement. Aspect, Brussels, Brussels, Belgium, 2010, p.107

[6] Bugajski, J. (2013) Dangers of Regression in the Western Balkans Atlantic council Negative Scenarios

[7] Denko Maleski, "Politicki Esei", Edicija Makedonija, Skopje 2012, 112-118

[8] Elbasani, A. (2013) 'Europeanization Travels to the Western Balkans: Enlargement Strategy, Domestic Obstacles and Diverging Reforms,' In Elbasani, A. (Ed.) European Integration and Transformation in the Western Balkans: Europeanization or Business as Usual? (Abingdon: Routledge), 3-22.

[9] Ekiert, G. and S. Hanson (eds.), 2003. Capitalism and Democracy in Central and Eastern Europe. New York: Cambridge University Press.

[10] G. Pridham and T. Gallagher (eds.), 2000. Democratisation in the Balkan Countries, in Experimenting with Democracy, Regime Change in the Balkans. London: Rouledge, pp. 1-24.

[11] Lisen Bashkurti, "Evropa, Ballkani dhe sfida e Kosovës, Geer Tiranë, 2006, 44-50

[12] Marko Bello, E Drejta Institucionale Bashkimit Evropian, (Shtepia Botuese Morava, Tirane 2010) 345-346.

[13] (European Commission, Enlargament Strategy, 2014-2015). 